\title{
SEASONAL PRODUCTIVITY AND COSTS PRODUCTION OF DUNALIELLA BARDAWIL UNDER EGYPTIAN CONDITIONS
}

\section{Tartiel El-Sayed Mohamed Badawy}

Central Laboratory for Aquaculture Research, Abbassa, Ecology and Biology Department, Agricultural Research Center, Ministry of Agriculture, Cairo, Egypt

\begin{abstract}
Microalgae are the natural feeds of many aquaculture species and are the basis of the natural food. This work aimed at the investigation of the possibility cultivation green algae Dunaliella bardawil under outdoor conditions (Egyptian conditions) was studied, variation in chemical composition of algal cells due to season of cultivation was also investigated and costs production. Average cell mass productivity reached the maximum in summer followed by autumn and spring. The algae were grown in batches using successively larger containers, the yield of the biomass, initial $\left(1.5 \times 10^{6}\right.$ cells $\left./ \mathrm{ml}\right)$ and final density $\left(12 \times 10^{6} \mathrm{cells} / \mathrm{ml}\right)$ of Dunalilla bardawil were obtained at four days culture 96 hours. Methods of drying significantly affected amino acid composition. Growth and chemical composition of Dunalilla bardawil cells are maximum crude protein content was around $52 \%$ for all seasons. Amino acid composition showed no significant difference between the batch cultures. Methionine was the limiting amino acid. The calculated average and maximum productivity of algal cells and crude protein showed the highest value in summer culture followed by autumn and spring seasons. The chemical composition of the algal powder was similar for all batches in percent of dry weight, $51.8 \%$ crude protein(C.P), $8.9 \%$ ether extract (E.E), $6.5 \%$ crude fiber (C.F), 9.2\% (ash), $23.6 \%$ N. free extract (NFE), and algal extracts containing antioxidant vitamins. The high cost of labor in the outdoor cultivation which represents approximately $49.26 \%$ from the total operating costs, followed by the nutrients, which recorded about $26.10 \%$ from the total costs, while the electricity had minimum cost recorded about $24.63 \%$ from the total costs. The harvesting of ton lives algae and oven dried gave $950 \mathrm{~g}$ dry biomass. The 1.052 ton live algae produced $1 \mathrm{~kg}$ dry biomass. The costs of Ingredient outdoor culture for producing live Dunalilla bardawil and operating dry biomass were about 15.30 Pound $\backslash$ ton of live algae and the costs of dry weight were LE 20.30 Pound, while operating costs were LE 21.37 Pound/kg dry biomass.
\end{abstract}

Key Word: Dunaliella bardawil, outdoor conditions, growth, chemical composition, Egypt.

\section{Introduction}

Microalgae have been investigated as a human and animal food for over 40 years, the use of microalgae in aquaculture has several potential advantages over the production of microalgae for human foods or terrestrial animal feeds such as high conversion efficiencies and no need for harvesting, drying and storage, as the animals or food chains could use the algae as produced. However, the production of microalgae for aquaculture feeds has been relatively neglected, mainly, because the aquaculture system themselves were generally poorly developed (Dam et al., 2002). A few years ago, microalgae have been increasingly produced for commercial purposes which include human and animal consumption, bioactive compounds for medicine, fuel production, biofertilizers, and as live 
feeds for the cultivation of filter feeding organisms. Currently, microalgal biomass production is economically feasible only when product values are relatively high, such as special chemicals and pigments, or when the microalgae play a critical role in aquaculture production (Spectorova et al., 1997). Different techniques of axenic algae production were developed, growing blue-green algae usually occur in abundance during the warm months of the year (Fogg, 1984). Out of the intensive research in many countries, one can conclude that, microalgae provide a valuable source of protein and other chemical compounds (Becker, 1994). Microalgae may provide such countries with a potential direct and indirect protein source which can be locally produced. In the commercial and semicommercial production of algae for feed and food, important advances have been made in South East Asia (De-Pauw et al., 1998; De-Pauw and Persoone, 2006).

Egypt has good potential for mass production of algae. Algae might be a good source for poultry and fish feed which is now being partially imported. Open-door mass production of algae is carried out in Egypt on experimental scale. This work aimed at the investigation of the possibility of the mass production of Dunalilla bardawil in outdoor cultivation under Egyptian conditions and to study, how successfully an algae production system for cultivation period and the growth rate during seasonal variations. Also variation in chemical composition of algal cells due to season of cultivation was also investigated.

\section{Materials and Methods}

\section{Basic medium and Algae culture:}

Bold basal medium according to Bischoff and Bold (1963) was used as nutrient solution for multiplication green microalgae Table (1). Algae cultures were incubated in the growth room at $25^{\circ} \mathrm{C}$, adjusted by air condition, continuous illumination provided by 6 fluorescent lamps (osram, cool white, $40 \mathrm{w} 120 \mathrm{~cm}$ ) which gave a light intensity of 5000 lux, light was supported by one side of light bank under photoperiods 14 light/10 hours, cycles. The $\mathrm{pH}$ was adjusted daily to 7.0 with additional 5 pellets of $\mathrm{KOH}$ (hydroxide potassium), while light intensity was measured daily and adjusted with Lux meter, as well as photoperiods were adjusted by electricity timer. The inoculum was prepared in laboratory, $250 \mathrm{ml}$ Erlenmeyer flasks each containing $100 \mathrm{ml}$. of sterilized media was inoculated with Dunaliella bardawil in a concentration of $1.5 \times 10^{6}$ cells $/ \mathrm{ml}$.

Table (1): Chemical composition of B.B.M. medium.

\begin{tabular}{|l|c|}
\hline \multicolumn{1}{|c|}{ Chemicals } & $\begin{array}{c}\text { Final } \\
\text { concentration }\end{array}$ \\
\hline A. Macronutrients: Consists of six stock solutions: \\
\hline 1-Sodium nitrate $\left(\mathrm{NaNO}_{3}\right)$ & $25 \mathrm{~g} / \mathrm{l}$ \\
\hline 2- Potassium dihydrogen phosphate $\left(\mathrm{KH}_{2} \mathrm{PO}_{4}\right)$ & $17.5 \mathrm{~g} / \mathrm{l}$ \\
\hline 3-Dipotassium hydrogen phosphate $\left(\mathrm{K}_{2} \mathrm{H} \mathrm{PO}_{4}\right)$ & $7.5 \mathrm{~g} / \mathrm{l}$ \\
\hline 4-Magnesium sulfate $\left(\mathrm{MgSO}_{4}\right)$ & $7.5 \mathrm{~g} / \mathrm{l}$ \\
\hline 5-Calcium chloride $\left(\mathrm{CaCl}_{2}\right)$ & $2.5 \mathrm{~g} / \mathrm{l}$ \\
\hline 6-Sodium chloride $\left(\mathrm{NaCl}_{2}\right)$ & $2.5 \mathrm{~g} / \mathrm{l}$ \\
\hline
\end{tabular}




\begin{tabular}{|l|c|}
\hline \multicolumn{2}{|c|}{ Consists of four stock solution: } \\
\hline $1-\mathrm{Na}_{2}-\mathrm{EDTA}+\mathrm{KOH}$ & $50 \mathrm{~g}$ plus 31 g/l \\
\hline $2-\mathrm{FeSO}_{4} \cdot 7 \mathrm{H}_{2} \mathrm{O}$ & $4.98 \mathrm{~g} / \mathrm{l}$ \\
\hline $3-\mathrm{H}_{3} \mathrm{BO}_{3}$ Boric acid & $11.42 \mathrm{~g} / \mathrm{l}$ \\
\hline $4-\mathrm{The}_{\text {following four salts: All dissolved in one liter volume distilled water }}$ \\
\hline$-\mathrm{ZnSO}_{4} \cdot 7 \mathrm{H}_{2} \mathrm{O}$ & $8.82 \mathrm{~g} / \mathrm{l}$ \\
\hline$-\mathrm{MnCl}_{2}$ & $1.44 \mathrm{~g} / \mathbf{l}$ \\
\hline$-\mathrm{CuSO}_{4}$ & $1.57 \mathrm{~g} / \mathbf{l}$ \\
\hline$-\mathrm{Co}_{4}\left(\mathrm{NO}_{3}\right)_{2} \cdot 6 \mathrm{H}_{2} \mathrm{O}$ & $0.49 \mathrm{~g} / \mathbf{l}$ \\
\hline
\end{tabular}

\section{Glass aquaria culture stages (outdoor):}

At the beginning of the experiment carboy bottle was used until cultures reached the harvestable density (log phase), then they were used to inoculate 100-liter glass aquaria $(75 \times 40 \times 60 \mathrm{~cm})$. Carboys and mass culture aquaria using air compressor of a 5-hp air blower. This aeration supplies suitable oxygen density and carbon dioxide concentration needed for algae propagation, keeps algal cells in suspension form and helps to stabilize $\mathrm{pH}$. The glass aquaria are cleaned and prepared for the experiment by filled it with tap water and added sodium hypochlorite to disinfect the system. After 24 hours the residual hypochlorite is neutralized with sodium thiosulfate. Atmospheric temperature was recorded daily by thermometer at three times intervals ( 9 a.m., 12 noons and 3 p.m.). Tap water was used to prepare the medium for all large scale culture experiments. The chemical analysis of tap water was presented in (Table 2).

Table (2): Physical and chemical analysis of tap water during three months.

\begin{tabular}{|c|c|c|c|}
\hline \multirow[t]{2}{*}{ Item } & \multicolumn{3}{|c|}{ Months } \\
\hline & September & October & November \\
\hline Temperature ${ }^{\circ} \mathrm{C}$ & $25.4 \pm 2.7$ & $24.2 \pm 1.9$ & $22.7 \pm 1.2$ \\
\hline Dissolved Oxygen & $6.3 \pm 0.3$ & $5.16 \pm 0.8$ & $6.73 \pm 0.4$ \\
\hline pH & $8.67 \pm 0.04$ & $8.36 \pm 0.02$ & $7.93 \pm 0.07$ \\
\hline Salinity (mg/l ) & $0.20 \pm 0.00$ & $0.22 \pm 0.00$ & $0.19 \pm 0.00$ \\
\hline $\mathrm{NH}_{4}(\mathrm{mg} / \mathrm{l})$ & $0.58 \pm 0.09$ & $0.47 \pm 0.06$ & $0.54 \pm 0.07$ \\
\hline $\mathrm{NH}_{3}(\mathrm{mg} / \mathrm{l})$ & $0.06 \pm 0.01$ & $0.08 \pm 0.03$ & $0.05 \pm 0.02$ \\
\hline $\mathrm{NO}_{3}(\mathrm{mg} / \mathrm{l})$ & $0.15 \pm 0.03$ & $0.11 \pm 0.07$ & $0.13 \pm 0.04$ \\
\hline Total solids(mg/l) & $272.3 \pm 12$ & $266 \pm 13$ & $265.3 \pm 11$ \\
\hline Total suspended solids & $145 \pm 2.4$ & $138 \pm 2.5$ & $151 \pm 3.0$ \\
\hline Total Alkalinity & $340 \pm 5.6$ & $348.6 \pm 6.1$ & $358 \pm 6.3$ \\
\hline Total Hardness & $299.3 \pm 5.2$ & $241.3 \pm 6.4$ & $249.6 \pm 5.9$ \\
\hline Total phosphorus & $0.28 \pm 0.01$ & $0.22 \pm 0.01$ & $0.29 \pm 0.02$ \\
\hline
\end{tabular}

Data are represented as mean of three samples replicates \pm standard deviation.

Also, the large scale cultures were disinfected according to Hemerick et al. (1973) by the addition of the commercial bleach, Clorox ${ }^{\circledR}$ at the rate of $5.25 \%$ solution as 
sodium hydrochlorite (NaOCL) and kept for one day under continuous aeration, amount of Clorox and sodium thiosulfate used to disinfect water presented in (Table 3)

Table (3): Amount of Clorox and sodium thiosulfate used to disinfect water.

\begin{tabular}{|c|c|c|c|}
\hline \multirow{2}{*}{ Chemicals } & \multicolumn{3}{|c|}{ Type } \\
\cline { 2 - 4 } & $\begin{array}{c}\text { Carboy } \\
(\mathbf{2 0} \text { l) }\end{array}$ & $\begin{array}{c}\text { Glass aquaria } \\
(\mathbf{1 0 0} \text { I) }\end{array}$ & $\begin{array}{c}\text { Tank } \\
(\mathbf{1 0 0 0} \text { l) }\end{array}$ \\
\hline Clorox $(\mathbf{m l})$ & 5 & 25 & 100 \\
\hline Sodium thiosulphate $(\mathrm{g})$ & $\mathbf{0 . 2}$ & $\mathbf{1 . 0}$ & 5 \\
\hline
\end{tabular}

Sodium thiosulfate is not added until 4 hours after the addition of clorox. ${ }^{\circledR}$

\section{Nutrients for outdoor algae cultures:}

The outdoor cultures were grown on a liquid foliar fertilizer which is marketed under "Complesal formula" amount of the following salts per 1000 liters tap water, each chemical dissolved separately in $100 \mathrm{ml}$ warm water before added to water tank, algae culture medium presented in Table (4). The Proximate chemical analysis was determined according to the methods described by A.O.A.C. (1995).

Table (4): Chemical composition of culture medium for outdoor cultivation.

\begin{tabular}{|c|c|c|c|c|}
\hline \multirow[t]{2}{*}{ Chemicals } & \multirow[t]{2}{*}{ Elements } & \multicolumn{2}{|c|}{ Composition } & \multirow{2}{*}{$\begin{array}{c}\text { Final } \\
\text { concentration } \\
(\mathrm{g} / \mathbf{1 0 0 0} \mathrm{l})\end{array}$} \\
\hline & & Weight (\%) & Volume (\%) & \\
\hline Sodium nitrate & $\mathbf{N}$ & 12.0 & 14.0 & 127 \\
\hline $\begin{array}{l}\text { Ammonium sulfate/ or } \\
\text { substituted with } \\
\text { potassium nitrate }\end{array}$ & P-S & 4.00-0.20 & $4.70-0.24$ & $\begin{array}{l}100 \\
187\end{array}$ \\
\hline $\begin{array}{l}\text { Mono potassium } \\
\text { phosphate }\end{array}$ & K-B & $6.00-0.02$ & $7.10-0.024$ & 30.0 \\
\hline $\begin{array}{l}\text { Fe-EDTA(Ethylene } \\
\text { diamine tetra acetic acid } \\
\text { disodium salt) }\end{array}$ & $\begin{array}{c}\mathrm{Mg} \\
\mathrm{Fe}\end{array}$ & $\begin{array}{l}\text { 0.16- } \\
0.010\end{array}$ & $\begin{array}{c}0.20 \\
0.012\end{array}$ & 15.0 \\
\hline \begin{tabular}{l} 
Minerals mixed mg\} $\\
{1000 \text { I ) zinc sulfate }} \\
{\text { Cobalt chloride }}$ & $\mathbf{Z n}$ & 0.001 & 0.000 & 2.2 \\
\hline Manganese Chloride & Mn & 0.010 & 0.012 & 35.0 \\
\hline Sodium mohybdate & Mo & 0.005 & 0.006 & 0.36 \\
\hline Cupric sulfate & $\mathbf{C u}$ & 0.010 & 0.012 & 9.8 \\
\hline
\end{tabular}
\end{tabular}

Algal biomass harvesting and Drying:

The quality of the algal biomass dried by the two methods was compared by determining their moisture and crude protein contents. Since cells of microalgae at the stationary phase of growth tended to settle to the bottom of the cultivation tank, primary 
separation of the algal cells from the liquid phase was achieved by gravity separation. After the algal culture reached maximum growth, the circulation provided by the pumping system was stopped and the algal cells settled and formed thick sediment at the bottom of the cultivation tank within 24hours (Allen and Nelson, 1974).

\section{Concentrated algal suspension:}

Centrifugation was used to concentrated algal suspension by automatic superspeed centrifuge at 5000 r.p.m for $10 \mathrm{~min}$. In order to find a suitable drying method, the algal pellet obtained by centrifugation was dried either: in an oven at $110^{\circ} \mathrm{C}$ for $15-20$ minutes, or oven-dried at $85{ }^{\circ} \mathrm{C}$ for $4 \mathrm{~h}$, then at room temperature. Crude protein was determined by using microkjeldahl methods according to APHA (1985).

\section{Statistical analysis}

Correlation coefficients, regression and Least Significant Difference (LSD) were carried out using the Analysis of variance (ANOVA) and Duncan's multiple Range Test (1996) to determine differences between treatments means at significance rate of $\mathrm{P}<0.01$. The standard errors of treatment means were also estimated. All statistics were carried out using Statistical Analysis system (SAS, 2000).

The present study was carried out in the Central Laboratory for Aquaculture Research (CLAR) and International Central Laboratory for Aquaculture Research Management. The World Fish Center, Regional Center for Africa and West Asia, Abbassa, Abu-Hammad, Sharkia, Egypt.

\section{Results and Discussion}

\section{1-Chemical composition and essential amino acid:}

The chemical composition of alga (table 5) showed that, the crude protein percentage was $(51.8 \%), 8.9 \%$ ether extract, $6.5 \%$ crude fiber, $9.2 \%$ ash, $23.6 \% \mathrm{~N}$. free extract and algal extracts containing antioxidant vitamins, B1, B2, B6, B12, E, C, Biotin, B-carotene and Folic acid ( $\mu \mathrm{g} \backslash \mathrm{g}$ dry weight) were found to be $28.4,18.6,23.0,0.8,12.0$, $166,0.9,85$ and 4.6 respectively these finding was more correlated to the content of Scenedesmus spp. and slight different to Chlorella spp. published by Tartiel (2005). As shown in Table (5), calcium content in the alga was $18 \mathrm{mg} / \mathrm{g}$ dry matter. This result was nearly similar to that of (Behr and Soeder, 2002). Broun (2000) reported nearly equal to figures to phosphorus and magnesium contents (12.5 and $10.2 \mathrm{mg} / \mathrm{g}$ dry wt. respectively) found in the present investigation. Also, potassium, sodium, iron, zinc, manganese, copper and lead contents are similar to those reported by (US EPA, 2007).

Table (5): Chemical composition, minerals content and vitamins content of Dunalilla bardawil.

\begin{tabular}{|l|c|l|c|l|l|}
\hline \multicolumn{1}{|c|}{ Chemical composition } & $\begin{array}{c}\text { \% on dry } \\
\text { matter } \\
\text { bases }\end{array}$ & Minerals & $\begin{array}{c}\text { mg/g } \\
\text { DW }\end{array}$ & Vitamin & $\begin{array}{c}\mu g / g \\
\text { DW }\end{array}$ \\
\hline Crude protein & $\mathbf{5 1 . 8}$ & Calcium & $\mathbf{1 8 . 0}$ & B1 & $\mathbf{2 8 . 4}$ \\
\hline Ether extract & \multirow{2}{*}{$\mathbf{n}$} & Phosphorus & $\mathbf{1 0 . 2}$ & $\mathbf{B 2}$ & $\mathbf{1 8 . 6}$ \\
\cline { 3 - 6 } & & Magnesium & $\mathbf{1 2 . 5}$ & $\mathbf{B 6}$ & $\mathbf{2 3 . 0}$ \\
\hline
\end{tabular}




\begin{tabular}{|c|c|c|c|c|c|}
\hline \multirow{2}{*}{ Crude fiber } & \multirow{2}{*}{6.5} & Potassium & 7.80 & B12 & 0.8 \\
\hline & & Sodium & 3.00 & $\mathbf{E}$ & 120 \\
\hline \multirow{2}{*}{ Ash } & \multirow{2}{*}{9.2} & Iron & 2.10 & C & 166 \\
\hline & & Zinc & 1.85 & Biotin & 0.9 \\
\hline \multirow{2}{*}{ Nitrogen free extract $*$} & \multirow{2}{*}{23.6} & Manganese & 0.22 & $\beta$-carotene & 85 \\
\hline & & Copper & 0.20 & Nicotinate & 77 \\
\hline $\begin{array}{l}\text { Gross energy } \\
\text { (Kcal/100g)** }\end{array}$ & 473.2 & Lead & 0.08 & Folic acid & 4.6 \\
\hline
\end{tabular}

*Nitrogen free extract $=100-$ (protein + lipid + ash + crude fiber $)$.

**Gross energy: Calculated according to NRC (1993) as 5.64, 9.44 and $4.11 \mathrm{kcal} / \mathrm{g}$ for protein, lipid and Nitrogen free extract, respectively.

From Table (6), Protein chemical score of samples taken from culture of spring and summer seasons was nearly the same and was relatively higher in the autumn season. Maximum crude protein content was around 52\% for all seasons. This was attained at the age of 8 days for spring and summer and at 12 days in autumn seasons. Nitrogen is the major component of proteins and amino acids, and is, after $\mathrm{C}, \mathrm{H}$ and $\mathrm{O}$, the most abundant element in living cells (Persoone $\boldsymbol{e t}$ al., 2009). Total nucleic acid content was about $4 \%$. Summer temperature naturally ranged higher that other two seasons and consequently, resulted in higher growth rate and protein productivity. However, analysis of variance comparing algal growth rate and yields of spring summer and autumn cultures were not significant. Maximum protein productivity value of Dunalilla culture was obtained in summer season followed by autumn and spring respectively (Table 6). Such data agree with higher growth rate in summer of green algae, investigated by Broun (2000). The start of the protein and the extent to which it declined varied with the season of cultivation. Lipids extracted by ether and total carbohydrates in the cells showed a spontaneous increase during the same period. The amino acid composition of the 3 species compared well with the FAO amino acid pattern except for methionine and isoleucine, in the study carried by Dam et al. (2002). They reported that bioassay evaluation of the algal proteins gave the following values: protein efficiency ratio 1.9 to 2.1 , net protein ratio 2.4 to 2.8 , biological value 75 to 78 , digestibility coefficient 88 to 89 and calculated net protein utilization 67 to 69, (Abd El-hakim and Badawy, 2008).

Table (6): Effect of seasonal variation on the combined amino acid of Dunalilla bardawil

\begin{tabular}{|c|c|c|c|c|c|c|c|}
\hline \multirow{2}{*}{ Amino acid } & \multicolumn{6}{|c|}{ Season } & \multirow{2}{*}{$\begin{array}{c}\text { FAO } \\
\text { Pattern* }\end{array}$} \\
\hline & Spring & S.\% & Summer & S.\% & Autumn & S. \% & \\
\hline Threonine & 6.4 & 7.4 & 6.2 & 6.6 & 6.6 & 7.4 & 2.8 \\
\hline Isolecucine & 4.2 & 5.5 & 5.8 & 6.1 & 4.6 & 5.1 & 4.2 \\
\hline Leucine & 9.6 & 11.2 & 8.2 & 8.7 & 7.8 & 8.6 & 4.8 \\
\hline Lysine & 6.5 & 4.9 & 5.4 & 5.7 & 4.0 & 4.5 & 4.2 \\
\hline Methionine*** & 0.1 & 0.12 & 0.1 & 0.1 & 1.0 & 0.01 & 2.2 \\
\hline Phenylalanine $* *$ & 2.8 & 3.2 & 4.2 & 4.4 & 3.5 & 3.9 & 2.8 \\
\hline Valine & 4.9 & 5.7 & 6.7 & 7.0 & 6.2 & 6.9 & 4.2 \\
\hline Tryptophane & 1.4 & 1.6 & 1.5 & 1.0 & 1.5 & 1.7 & 1.2 \\
\hline Histidine & 1.2 & 1.4 & 1.3 & 1.4 & 1.4 & 1.6 & \\
\hline
\end{tabular}




\begin{tabular}{|l|c|c|c|c|c|c|}
\hline Arginine & 6.8 & 7.4 & 6.5 & 6.9 & 6.3 & 7.0 \\
\hline Aspartic acid & 8.5 & 9.8 & 10.0 & 10.5 & 10.0 & 11.2 \\
\hline Serine & 3.2 & 3.7 & 5.0 & 5.3 & 4.1 & 4.6 \\
\hline Glutamic acid & 12.0 & 13.9 & 12.4 & 13.1 & 10.4 & 11.6 \\
\hline Proline & 4.0 & 4.6 & 4.2 & 4.5 & 4.4 & 4.9 \\
\hline Glycine & 5.1 & 5.9 & 4.8 & 5.0 & 5.1 & 5.7 \\
\hline Alanine & 8.2 & 9.5 & 8.1 & 8.6 & 8.3 & 9.3 \\
\hline Tyrosine & 3.5 & 4.0 & 3.8 & 4.02 & 4.1 & 4.6 \\
\hline Ornithine & 0.1 & 0.1 & 0.2 & 0.2 & 0.2 & 0.22 \\
\hline Total amino acids & \multicolumn{2}{|c|}{88.5} & \multicolumn{2}{c|}{89.4} & & \\
\hline
\end{tabular}

S. $\%=$ Score $\%$ of total amino acids; $*$ Recommended essential amino-acid content for an ideal protein for animal consumption (WHO/FAO) (Bhumiratana, 1976). **Essential amino acids in Dunalilla bardawil g/100g protein. Algal samples containing crude protein level (dry weight basis).

\section{2-Seasonal variations:}

The growth of algae is essentially dependent on nutrient composition, $\mathrm{H}$-ion concentration of the medium, temperature, light and adequate agitation of the culture (Munoz et al., 2007; Edmondson, 2006). Table (7) indicates that the calculated average and maximum productivity of algal cells and crude protein showed the highest value in summer culture followed by autumn and spring seasons (Felts and Heath., 1984; Dam et al., 2002; Yang and Huang, 2007). Growth curves showed a lag phase from zero to three days for spring and autumn seasons. Logarithmic growth phase continued until 15 days for spring, 30 days for summer 18 days for autumn seasons. Decline of growth rate started after 24 and 21 days for summer and autumn seasons. Becker (1994) suggested that, the nutritional status as well as surrounded environmental growth conditions limited both growth and cellular component of green algae. In this respect, the environmental factors may be both physical, such as temperature and light, and chemical, which provide all raw materials used for the structural and protoplasmic synthesis of the algal cells. The amino acid composition of the 3 species compared well with the FAO amino acid pattern except for methionine and isoleucine, in the study carried by Dam et al. (2002).

The growth of algae can be limited by insufficient illumination, low temperature, and low concentration of a biologically important element on the medium or its low rate of diffusion from the medium into the cells. It is suggested that the variation in temperature and light intensities resulted in lower productivity in spring season Dam et al. (2000) reported that green algae cultured in summer have been characterized by higher growth rate, followed by autumn and winter. This phenomenon has been attributed to the decrease of temperature in these seasons. Maximum protein productivity value of culture was obtained in summer season followed by autumn and spring respectively, (Tables 6 and 7). Such data agree with higher growth rate in summer of green algae, investigated by Soeder et al. (2003). The start of the protein and the extent to which it declined varied with the season of cultivation. Lipids extracted by ether and total carbohydrates in the cells showed a spontaneous increase during the same period. 
Table (7): Variation in the amino acids composition with level of crude protein in Dunalilla bardawil grown at outdoor conditions. (Data expressed as g/100g protein).

\begin{tabular}{|l|c|c|c|c|c|}
\hline \multirow{2}{*}{ Amino acid } & \multirow{2}{*}{$\begin{array}{c}\text { FAO } \\
\text { pattern }\end{array}$} & \multicolumn{2}{c|}{ Maximum protein } & \multicolumn{2}{c|}{ Minimum protein } \\
\cline { 3 - 6 } & & Amino acid & S.\% & \multirow{2}{*}{ Amino acid } & S..\% \\
\hline Threonine & 2.8 & 6.4 & 228 & 5.1 & 182 \\
\hline Isolecucine & 4.2 & 4.8 & 30.7 & 3.7 & 88 \\
\hline Leucine & 4.8 & 9.7 & 202 & 7.5 & 156 \\
\hline Lysine & 4.2 & 4.2 & 100 & 3.0 & 71 \\
\hline Methionine & 2.2 & 0.1 & 4.5 & 0.7 & 31 \\
\hline Phenylalanine & 2.8 & 2.8 & 100 & 2.9 & 103 \\
\hline Valine & 4.2 & 4.9 & 116 & 4.6 & 109 \\
\hline Tryptophane & 1.2 & 1.4 & 117 & 1.2 & 100 \\
\hline Histidine & -- & 1.2 & -- & -- & -- \\
\hline Arginine & -- & 6.4 & -- & -- & -- \\
\hline Aspartic acid & -- & 8.5 & -- & -- & -- \\
\hline Serine & -- & 3.2 & -- & -- & -- \\
\hline Glutamic acid & -- & 12.0 & -- & -- & -- \\
\hline Proline & -- & 4.0 & -- & -- & -- \\
\hline Glycine & -- & 5.1 & -- & -- & -- \\
\hline
\end{tabular}

* Recommended essential amino-acid content for an ideal protein for animal consumption (WHO/FAO) (Bhumiratana, 1976). " S. \% Score\% of FAO pattern. "* Essential amino acids in Dunalilla bardawil g/100g protein.

\section{3-Mass production of Dunalilla bardawil}

The duration of each batch population depended on growth rate $\left(\mathrm{g} / \mathrm{m}^{2}\right)$ which varied from one batch to another according to climatic condition (especially temperature), the obtained results showed that highest productivity was recorded during May-September and lowest during December-March. The algal yield (ton/feddan/year) calculated according to the average of daily productivity during the cultivation period $\left(12-17 \mathrm{~g} / \mathrm{m}^{2}\right)$ was $14-21$ ton/feddan/year (300 days duration) are shown in Table (8). The time required for airdrying the algae was dependent on some environmental factors such as relative humidity, temperature, evaporation rate and light intensity. Qualities of the algal biomass dried by the two methods were compared by determining the moisture and crude protein contents of the dried algal biomass. Oven drying at $110^{\circ} \mathrm{C}$ was for drying the harvested algal cells because a much shorter drying time was required. El-Fouly et al. (1998) reported that total ash of Chlorella decreases proportionally with the decrease in crude protein. However, we might explain these results on the basis that Anabaena culture was uncovered. Consequently contamination with atmospheric dust was possible. In this respect De Pauw et al. (1998) mentioned that site selection is one of the most important factors which can increase net productivity of algae, added that micro algae plant should be located at site where climatic conditions provide optimal growth conditions for the longest possible period. The yield from 3 large-scale cultures of Scenedesmus acutus, Chlorella vulgaris and Coelastrum 
proboscideum was drum dried. Delorenzo et al. (2009) reviewed that; commercially the large-scale production of $H$. pluvialis must also carefully controlled. Where, growth rate was reduced at higher temperature and the best growth was obtained between 15 and $25^{\circ} \mathrm{C}$. However, at $28^{\circ} \mathrm{C}$ growth was inhibited and at $35^{\circ} \mathrm{C}$ the culture died. Also, relatively high culture temperature may lead to enhanced carotenoids formation and or higher reactivates of active oxygen in the algal cell (Yan $\boldsymbol{e t}$ al., 2010). In natural habitat, the aplanospore formation in H. lacustris in small ponds is directed more or less at with standing during out, high irradiation and light, results indicated that the sulphur amino acids are the most limiting amino acids in algae, while histidine and iso-leucine were the second and third limiting amino acids. From the aforementioned results, it is evident that the green alga Dunalilla bardawil can be cultivated under the Egyptian outdoor conditions. The cultivation can be carried out all year around. The modified production system proved to be efficient and the technology used in adequate and appropriate. All conditions for algal growth turbulence and agitation, $\mathrm{Co}_{2}$, nutrient solution, recycling, $\mathrm{pH}$ adjustment were regularly checked. The produced alga dry material can be used as a supplement to poultry and fish feed (Badawy et al., 2008).

\section{4- Construction and running the production unit}

El-Fouly et al. (1998) described The unit with $245 \mathrm{~m}^{2}$ of basins surface area, consists of four small ground basins $5 \mathrm{~m}^{2} /$ each and three big basins of $75 \mathrm{~m}^{2} /$ each. These varying increases are proportional with decreases of crude protein content of algal cells cultivated in different seasons. Meanwhile, the increase of indigestible polysaccharides content is related to the increase of carbohydrates in the same samples. The high percentage of silica content (about 50\% of total ash as shown in results were also in accordance with those obtained by Wang $\boldsymbol{e t}$ al. (2007), they reported that the context of threats to fragile environments, there is a need in animal production to identify alternative feed resources, which are environmentally friendly, but at the same time utilize natural resources efficiently. When a culture grows under optimum conditions its growth curve follows a sigmoid pattern in which at least five phase in the life of the culture may be recognized. They are namely: log phase, logarithmic phase, linear phase, stationary phase and death phase (Becker, 1994). This phenomenon could be attributed to high temperature and high sunlight intensity during these seasons, which led to photo-inhibition. Other studies on growth of green and blue-green algae under outdoor cultivation conditions gave similar results as reported by El-Fouly $\boldsymbol{e t}$ al. (1998). The green algae require, for optimum growth, temperature in the culture liquid between $26^{\circ} \mathrm{C}$ and $32^{\circ} \mathrm{C}$, the irradiation should exceed $600 \mathrm{Cal} / \mathrm{m}^{2}$ per day. Conditions like these exist in Egypt all the round, which allow high and stable yield with optimum efficiency of equipment utilization. On the other hand, it was observed that the amount of protein was within the same range for all cultures $(1.3-$ $1.6 \mathrm{~g} / \mathrm{L}$ ) in spite of the differences in algal yields. The latter values were 3.18 , and $1.8 \mathrm{~g} / \mathrm{L}$. for spring and autumn seasons, respectively. Lower dry matter yield in summer and autumn seasons resulted probably form the death of algal cells at the age of 36 and 30 days respectively. Death of cells could be attributed to photosynthesis inhibition which has been reported in other studies. Fan et al. (1994); Yan et al. (2010) and Delorenzo et al. (2009) reported that production of Spirulina in Southern France was $12 \mathrm{~g} / \mathrm{m}^{2} / \mathrm{day}$, and its protein 
content was $64-70 \%$ of the dried matter and variation in the raw protein content might be observed, especially when nitrogen was lacking in the medium.

Table (8): Average values of atmospheric and growth rate during cultivation months.

\begin{tabular}{|c|c|c|c|c|c|}
\hline Season & Month & $\begin{array}{c}\text { Average daily } \\
\text { temperature } \\
{ }^{\circ} \mathbf{C}\end{array}$ & $\begin{array}{c}\text { Radiation } \\
\text { Cal.cm²/day }^{2}\end{array}$ & $\begin{array}{c}\text { Cell yield } \\
\mathrm{g} / \mathrm{m}^{2}\end{array}$ & $\begin{array}{c}\text { Growth rate } \\
\mathrm{g} / \mathrm{m}^{2} / \text { day }\end{array}$ \\
\hline \multirow{3}{*}{ Winter } & December & $12-19$ & 250-300 & $120-135$ & $12-14$ \\
\hline & January & 10-17 & 270-300 & $120-140$ & $12-15$ \\
\hline & February & $14-20$ & $330-360$ & $110-140$ & $10-14$ \\
\hline \multirow{3}{*}{ Spring } & March & $18-22$ & $450-500$ & $110-140$ & $10-13$ \\
\hline & April & $19-24$ & 450-570 & $120-145$ & $12-14$ \\
\hline & May & $24-28$ & $600-630$ & $120-155$ & 13-15 \\
\hline \multirow{3}{*}{ Summer } & June & $28-30$ & $650-680$ & $140-160$ & 14-17 \\
\hline & July & $28-32$ & 650-680 & $130-160$ & 13-17 \\
\hline & August & $28-34$ & $600-640$ & $125-155$ & $14-16$ \\
\hline \multirow{3}{*}{ Autumn } & September & $25-28$ & $520-560$ & $125-145$ & $14-16$ \\
\hline & October & $23-26$ & $420-460$ & $120-140$ & 13-15 \\
\hline & November & $17-24$ & 310-340 & $110-130$ & $12-14$ \\
\hline
\end{tabular}

\section{5-Economic evaluation:}

The operating costs of producing one ton of microalgae using the multi-step method were LE 12.25/ton live algae (Table 9). The harvesting of ton live algae and oven dried gave $700 \mathrm{~g}$ dry biomass. The 1.43 ton live algae produced $1 \mathrm{~kg}$ biomass. Various artificial feeds such as freeze-dried or processed natural products have been developed to substitute, if not eliminate, the use of microalgae in the hatcheries, but the technique was not adopted by hatchery operators due to the additional skill and equipment needed.

Table (9): Final density and biomass yield of Dunalilla bardawil after 76 hour.

\begin{tabular}{|l|c|}
\hline \multicolumn{1}{|c|}{ Item } & Dunalilla bardawil \\
\hline Initial density (cells/ml) & $1.5 \times 10^{6}$ \\
\hline Final density (cells/ml) & $12 \times 10^{6}$ \\
\hline Dry weight (g/l) & 0.950 \\
\hline Dry weight of biomass yield (g/ton) $1 \mathrm{~m}^{3}$ water & 950 \\
\hline Biomass yield / kg dry weight & 1052.63 L. culture \\
\hline
\end{tabular}


Shelef $\boldsymbol{e t}$ al. (2005) reported that depending on the production and use of microalgae as live food for commercially important fish, mollusks and crustaceans during at last part of their life cycle.

Table (10) and Figure (1) shows the costs of $1 \mathrm{~kg}$ dry biomass of Dunalilla bardawil. The multi-step method is an efficient; it is a simple technique and can easily be adopted by fish hatchery operators (Fulks and Main, 1996). The minimal costs involved using this method make it an applicable technique for the mass culture of Dunalilla bardawil showed that examined algae could be utilized in Nile tilapia (Oreochromis niloticus) diets up to $50 \%$ instead of the dietary ingredient without any adverse effects on fish growth performances, feed utilization parameters and body composition (Spectorova et al., 1997 and Badawy et al., 2008). The use of microalgae as fish feed inputs has been studied with encouraging results. (Broun, 2000), reported positive growth performance in fish feed diets containing algae cells. Algae have attention as a possible alternative protein source for cultured fish, particularly in tropical and subtropical regions where algae production high and their good protein, vitamins and essential fatty acids contents.

Table (10): Total Costs of producing live microalgae and operating dry biomass of Dunalilla bardawil grown outdoor culture after 3 days for cultivation.

\begin{tabular}{|l|c|c|}
\hline \multicolumn{1}{|c|}{ Ingredient } & Total cost (Pound) & \multirow{2}{*}{ Percentage ( \% )of total } \\
\hline Inoclum of outdoor & $1.70 \mathrm{LE}$ & \multirow{2}{*}{$26.10 \%$} \\
\hline Clorox & $0.75 \mathrm{LE}$ & \\
\hline Nutrient & $2.85 \mathrm{LE}$ & \multirow{2}{*}{$\mathbf{2 9 . 2 6 \%}$} \\
\hline Labor & $10.0 \mathrm{LE}$ & \multirow{2}{*}{$\mathbf{2 4 . 6 3 \%}$} \\
\hline Electricity & $5.0 \mathrm{LE}$ & \\
\hline Cost of live algae/ton & $15.30 \mathrm{LE}$ & \\
\hline Cost of dry weight & $20.30 \mathrm{LE}$ & \\
\hline Total operating cost/1kg dry weight & $21.37 \mathrm{LE}$ & \\
\hline
\end{tabular}




\section{Total cost}

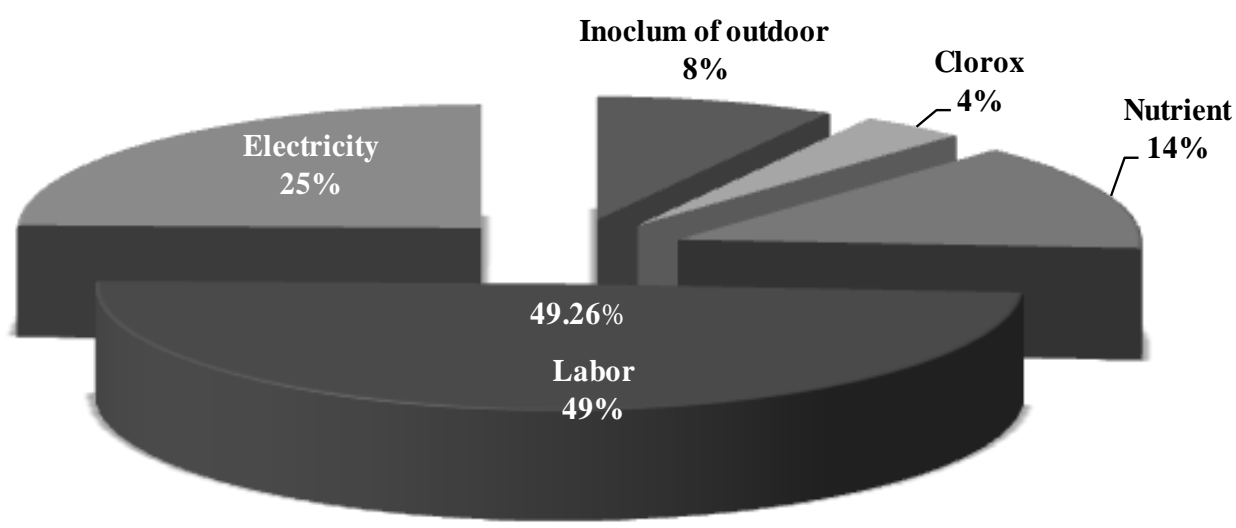

Figure (1): Percentage of total costs producing examined grown in outdoor at four days for cultivation

In conclusion, Egypt has an arid climate with maximum irradiation, offering the best conditions for photosynthetic productivity. Variation of day-length is not considered to be of importance with respect to algal yields. The fluctuations of temperature during the seasons might be compensated by choice of appropriate algal species. Algae have been utilized traditionally as food supplements and as a source of fine and valuable chemicals for various medicinal purposes. Uses include traditional cosmetics as antiseptic compounds. Microalgae are now considered one of the non-conventional source of vitamins, they contain several water and lipid-soluble vitamins, vitamins are presented in higher concentrations in Dunalilla bardawil than in conventional foods, some of the vitamins, are of particular commercial interest such as vitamin $\mathrm{E}$ (tocopherol), vitamin $\mathrm{C}($ ascorbic acid), $\beta$-carotene (pro-vitamin A) and vitamin B12. Ascorbic acid has been shown to reduce some potentially harmful genetic alterations. It was clear that Egypt has good potential for mass production of algae.

\section{Acknowledgments}

The candidate wishes to express her deep gratitude and my deep thanks to Prof. Dr. Eglal Mohamed Zaki Harb, Department of Botany, Cairo University, special thanks and deepest gratitude to Prof. Dr. Nabil Fahmy Abdel Hakim, Al-Azhar University for his great 
help and would like to thank Prof. Dr. Gamal El-Naggar, for his great help the whole work with continuous support, World Fish Center, Regional Center for Africa and West Asia, Abbassa, Abu- Hammad, Sharkia, Egypt.

\section{References}

A.O.A.C. Association of Official Analytical Chemists (1995). Official Methods of Analysis Association of Official Analytical Chemists. Edit., KHL rich. Arlington Virginia.

Abd El-Hakim, N. F. and Badawy, Tartiel M.E. (2008). Seasonal productivity and chemical composition of mass cultured Anabaena wisconsinense and Spirulina platensis under Egyptian conditions. Egyptian Journal of Phycology, 9:211233.

Allen, E. J. and Nelson, E.W. (1974). On the artificial culture of marine plankton organisms. J. Mar. Biol. Assoc., 8:421-474.

American Public Health Association (APHA) (1985). Standard methods for the examination of water and wastewater, edition American Public Health Association, Washington, D. C., USA.

Badawy, Tartiel M.E. (2005). Physiological studies on some green algae. Ph.D. thesis, Faculty of Agriculture, Cairo University. Egypt.

Badawy, Tartil M.E. and Al-Kenawy, Diaa A. (2009). Utilization of blue green alga (Anabaena wisconsinense) as a feeding and biofertilization for Nile tilapia cultivation in rice fields. Egyptian Journal of Phycology, 10:367-381.

Badawy, Tartiel M.E.; Ibrahim, E. M. and Zeinhom, M. M. (2008). Partial replacement of fish meal with dried microalga (Chlorella spp. and Scenedesmus spp.) in Nile tilapia (Oreochromis niloticus) diets. $8^{\text {th }}$ International Symposium on Tilapia in Aquaculture. (ISTA VIII), Cairo International Convention Center (CICC). Egypt, pp. 801-811.

Becker, E.W. (1994). Microalgae, Biotechnology and Microbiology. Cambridge Univ. Press, pp. 9-39.

Behr, W. and C. J. Soeder. (2002). Economic aspects of the mass production of microalgae. Proc. $2^{\text {nd }}$ Egypt. Algae Symp., Cairo. pp. 72-85.

Bhumiratana, A. (1976). The production and utilization of Algae as a Protein source in Thailand. Kasetsart University, Bangkok, 90 pp.

Bischoff, H . W . and Bold, H.C. (1963). Phycological studies. 4 some soil algae from Erchanted rock and related algal species. Univ. Texas, 8: 32-36.

Boyd, C. E. (1973). Summer algal communities and primary productivity in fish ponds. Hydrobiol., 41: 357-390. 
Broun, W. (1980). Note on the survival of algal resting cells during long-term maintenance in darkness and minimum lake bottom temperature. Comparison of Anabaena, 5:677-680.

Dam, R.; Lee, S. K.; Fry, P.C. and Fox, H. M. (2002). Utilization of algae as a protein source for humans. J. Nutr., 86:376-382.

DeLorenzo, M. E.; Leatherbury, M.; Weiner, J. A. and Fulton, M. H. (2009). Physiological factors contributing to the species-specific sensitivity of four estuarine microalgal Exposed to the Herbicide Atrszine. Aquat. Ecosyst. Health Manage, 7:137-146.

De-Pauw, N. and G. Persoone. (2006). Microalgae for aquaculture. Algal Biotechnology, Cambridge University, Press, New York. Pp.16-224.

De-Pauw, N.; Verboven, J. and Claus, C. (1998). Large-scale microalgae production for nursery rearing of marine bivalves. Aqua Cultural Engineering, 116/ 117:121134.

Edmondson, W. T. (2006). Eutrophication in North America, eutrophication causes consequences. Washington, D.C., USA., 124-149.

El-Fouly, M. M.; Abdalla, F. E. and Saleh, A. M. (1984). Studies on out-door mass culture of green alga Chlorella vulgaris. Effect of nitrogen efficiency in growth medium. Al-Azhar Agric. Bull., 22:l-14.

El-Fouly, M. M.; Soeder, C. J.; Mohn, F. H. and Greoneweg, J. (1998). Open door mass production, chemical composition and biological evaluation of different algal species. Bull. Egypt, 2: 149-165.

Fan, L.; Vonshak, A. and Boussiba, S. (1994). Effect of temperature and irradiance on growth of Haematococcus pluvialis. J. Phycol., 30:829-833.

FAO (1999). FAO training series 21/1. Simple methods for aquaculture, management for fresh water fish culture and water practices, Rome, Italy.

Fee, E.J. (2006). A relation between lake morphometry and primary productivity and its use in interbreeding whole. Lake eutrophication experiments. Limnol. Oceanger., 24: 401-416.

Felts, P.A. and Heath, A.G. (1984). Interactions of temperature and sublethal environmental copper exposure on the energy metabolism. J. Fish Biol., 25: 445-453.

Fogg, G.E. (1984). Algal cultures and phytoplankton ecology. University of Wisconsim Press, pp. 37-51.

Fulks, W. and Main, K. L. (1996). The design and operation of commercial scale live feeds production system. Fisheries Research Technical. 1:16-20.

Hemerick, G ; Hoshow, R. W. and Rosowski, J. R. (1973): Methods for algae, Handbok of phycological methods and growth measurements. Cambridge university press, London, pp:53-68. 
Munoz, R.; Kollner, C.; Guieysse, B. and Mattiasson, B. (2004). Photosynthetically oxygenated salicylate biodegradation in a continuous stirred tank photobioreactor. Center for Chemistry and Chemical Engineering, Lund University, 6:797-803.

NRC (Nutrient Requirements of Fishes) (1993). National Research Council, Nutrient Requirements of Domestic Animals, 128 pages.

Persoone, G.; Morales, J. and Claus, C. (1988). Mass culture of algae bottleneck in the nursery culturing of molluscs. Algae biomass. Elsevier/North-Holland Biomedical Press, New York., USA.

S. A. S. Statistical Analysis Systems. (2000). SAS program Ver. 6. 12,SAS institute incorporation. Cary. NC 27513 USA.

Shelef, G.; Moraine, R. and Oron, G. (2005). Economic aspects of microalgae production " microalgae for food and feed " Limnol. 201-204.

Soeder, C. J. (2003). The technical production of microalgae and prospects in marine aquaculture. Plenum Press. New York, 39-55.

Spectorova, A.; Montesinos, J. L.; Cusido J. A. and Godia, F. (1997). Recovery and treatment of Spirulina platensis cells cultured in a continuous photobioreactor to be used as food. Process Biochem., 37: 535-547.

Taha, E. M. and Allam, A. M. (1959). Physiological and biochemical studies on Egyptian fresh water algae. V. Growth and cell protein influenced by culture conditions. Arch. Microbiol., 34:393-400.

US EPA; United States Environmental Protection Agency (2007). National Recommended Water Quality Criteria Correction Office of Water, EPA 822-z99-001, 25 pp.

Wang, S.M.; Wang, Q.L.; Li, S.H. and Zhang, J. R. (2007). A study of treatment of spring wheat with growth promoting substances from nitrogen-fixing bluegreen algae. Academia Sinica, Wuhan, Hubei, China,1:45-52.

Yan, G.; Yu-Jing, Y.; Wang, X. and Wang, Y.X. (2000). The effects of pH and temperature on orthophosphate removal by immobilized Chlorella vulgaris. Biotechnology Letters, 18(8):893-896.

Yang, J. X. and Huang, X.F. (2007). Effects of environmental factors on the hatching rate of eggs (Rotatoria: Monogononta). Acta Hydrobiologica Sinica, 4: 331339. 


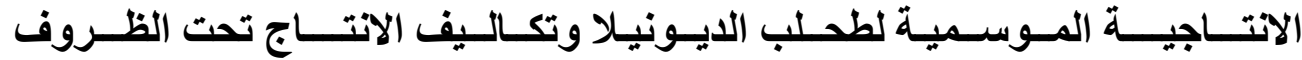 الـبيئية المصريـة البـانة

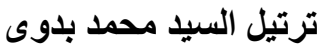 \\ قسم بحوث البيئة و البيولوجىـ الدعمل المركزى لبحوث الثروة السمكية بالعباسة ـ مركز البحوث الزراعيةـ وزارة

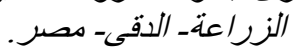

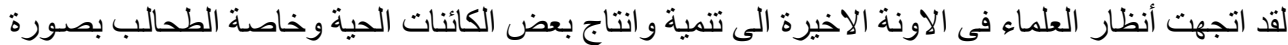

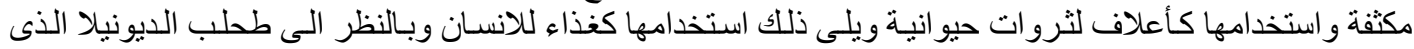

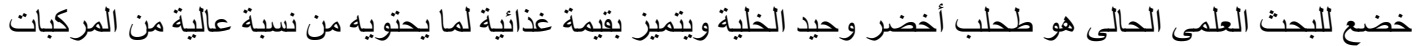

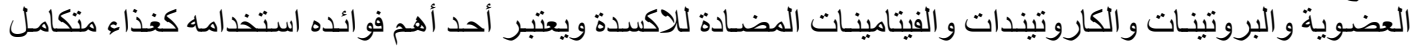

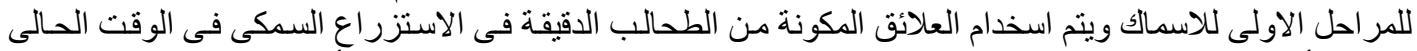

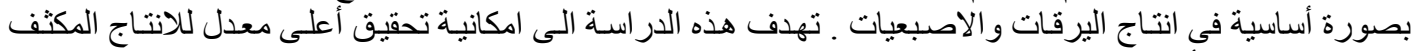

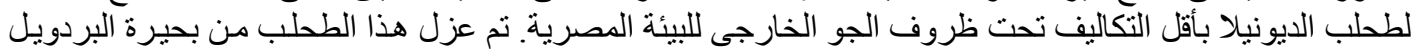

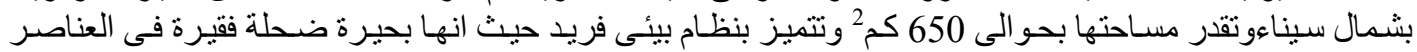

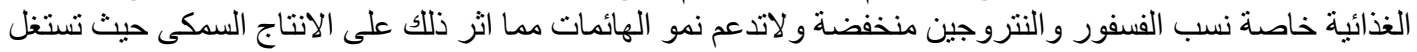

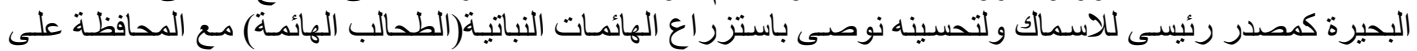

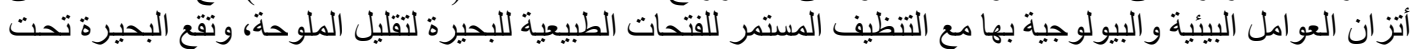

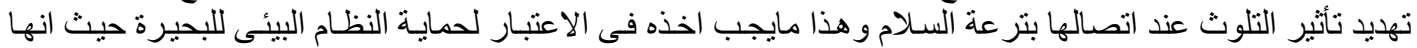

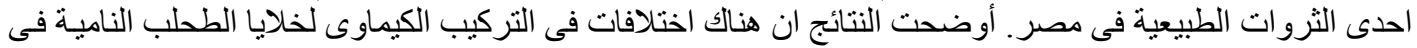

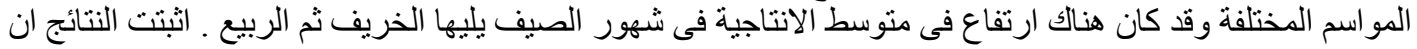

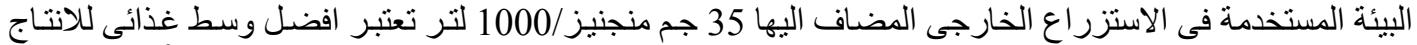

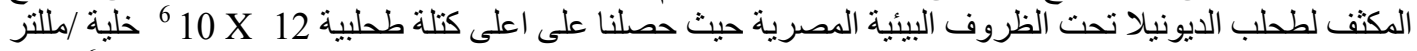

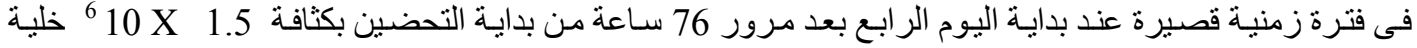

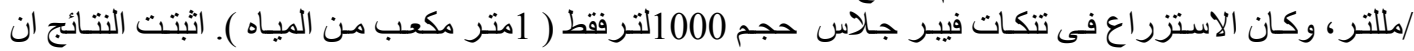

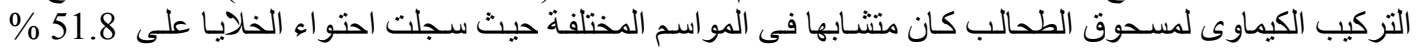

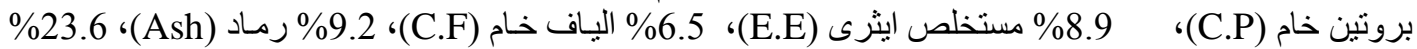

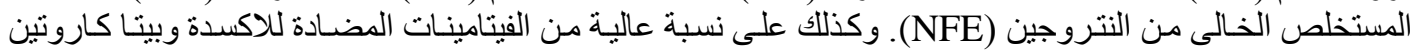

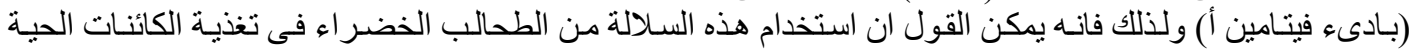

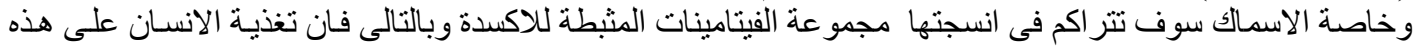

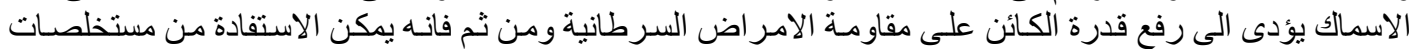

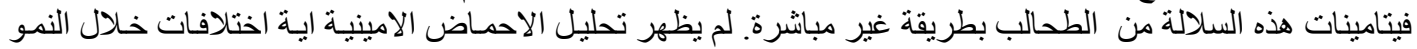

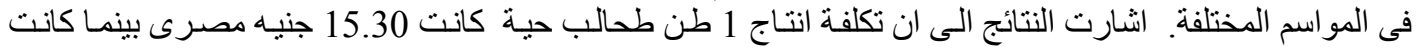

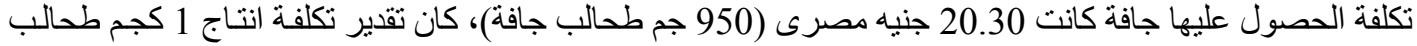

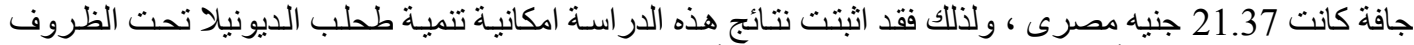
البيئية المصرية وتحقيق أعلى معدل انتاج لخلايا الطحلب بأقل التكاليف. 